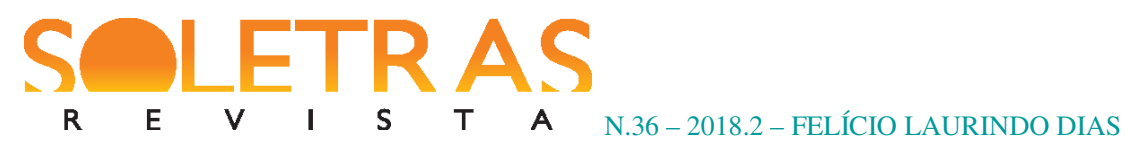

\title{
A situação da narrativa contemporânea hoje Entrevista com Julián Fuks ${ }^{1}$
}

\author{
$p o r$
Felício Laurindo Dias
}

Soletras: No cenário da produção literária de hoje, como vê o tipo de literatura que você produz em relação ao mercado literário?

É muito difícil você olhar pra o presente da literatura e da narrativa e não enxergar diversidade, multiplicidade etc. É um tempo em que nada se assentou, nada prevaleceu sobre o outro, nada se esqueceu, está tudo convivendo simultaneamente. De partida, é possível dizer que essa é uma das marcas do contemporâneo, mas tem que ter muita cautela com essa noção, porque em qualquer tempo você tem essa multiplicidade de discursos e projetos estéticos ou essa multiplicidade. A partir disso, no cenário brasileiro contemporâneo, penso que, perfis que antes não tinham tanto espaço no meio literário, lentamente têm ganhado vozes. Nesse ponto, a literatura brasileira tem sido mais diversa pelos perfis dos autores e das autoras, como, por exemplo, mais mulheres escrevendo, mais literatura de autoria negra, a presença de uma literatura de periferia que vai ganhando força, talvez não tão bem abarcada e assimilada pelo mercado ainda, mas de outras maneiras, como a força que emerge dos saraus de periferia, Slam Poetry e essas coisas que você vê e que são elementos que estão ganhando bastante força e vida no cenário contemporâneo. Mas há, também, um tipo de literatura mais ligado ao mercado editorial, mais assimilado e mais aceito, e que tem para mim como fenômeno mais interessante o hibridismo, ou melhor, a narrativa que não se constitui mais como pura. Nesse caso, aspectos mais tradicionais na ficção, que marcavam em certa medida o romance tradicional, como o nome próprio para esse sujeito, a invenção de peripécias para a vida desse sujeito, os enredos lineares e cronológicos e o caráter biográfico entram em crise. Dentro

\footnotetext{
${ }^{1}$ Julián Fuks é escritor e crítico literário. Nasceu em São Paulo, em 1981. Doutorou-se em Letras pela Universidade do Estado de São Paulo. Em 2012, foi eleito pela revista Granta um dos vinte melhores jovens escritores brasileiros. Em 2016, ganhou o Prêmio Jabuti na categoria romance por A resistência (São Paulo: Companhia das Letras, 2015). É doutorando em Teoria Literária e Literatura Comparada pela Universidade de São Paulo e Mestre em Literatura Hispano-Americana pela mesma universidade, instituição onde se graduou em Jornalismo. Fuks é especialista em Estética e Teoria da Arte pela Universidad Autónoma de Barcelona (UAB).

${ }^{2}$ Felício Dias é graduado em Letras pela Faculdade de Formação de Professores da UERJ e mestre em Letras pelo Programa de Pós-Graduação em Letras do Instituto de Letras da UERJ. Atualmente cursa o Doutorado em Teoria e História Literária na Universidade Estadual de Campinas. Suas pesquisas estão voltadas para os estudos de Teoria Literária e Literatura Brasileira Contemporânea.
} 


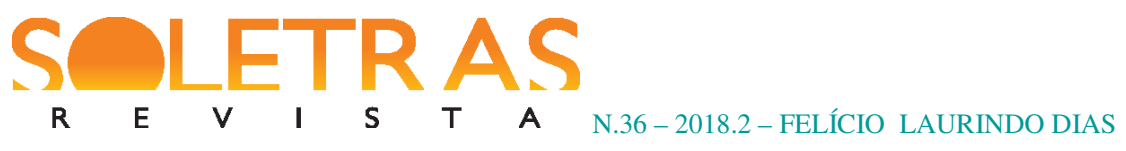

desse panorama, uma resposta contemporânea a essa mudança tem sido a imersão de certos discursos alheios à literatura dentro da própria literatura, no momento em que a ficção se deixar permear pela autobiografia, pelo ensaio, pela filosofia, pela historiografia. São discursos um pouco destoantes da literatura, embora a literatura sempre tenha se relacionado com eles, mas que agora deixam se assimilar de forma muito mais sistemática e mais extrema. Sinto que a tendência de mercado é de certa perplexidade diante desse fenômeno e ao mesmo tempo uma aceitação, o que não quer dizer que o mercado se indispôs com esse tipo de discurso. Tudo bem que antes você tinha no mercado editorial uma tendência a valorizar o tradicional, mas agora o mercado editorial em si se abriu para narrativas mais estranhas, romances feitos hoje e que têm bastante circulação, que têm sido razoavelmente lidos e conquistado prêmios. Aliás, a gente sabe que premiação agora é diferente, é claramente de um mercado, ou seja, de apreciação da crítica e do público consumidor. Acho que esse panorama começa a responder a sua questão e essa entrevista, e tudo que a gente começar a falar agora tem certa relação com isso.

Soletras: O historiador marxista Eric J. Hobsbawm, em sua Era dos Extremos, vê o século XX como um século curto, porém também o mais violento e catastrófico. Muitas produções artísticas e literárias representam esses eventos catastróficos por meio da memória, trazendo à cena representações de guerras e Holocaustos, como o genocídio de Ruanda, os embates na faixa de Gaza, o terrorismo, o Onze de Setembro, as mortes e torturas sofridas nos regimes ditatoriais no mundo. A partir dessa afirmação, gostaria de saber: como você vê as narrativas de hoje diante desse contexto de rastros, vestígios e fantasmas dos modelos políticos do século $\mathrm{XX}$, consolidados no seio desses acontecimentos de barbárie e que nos visitam talvez nem mais indiretamente, mas diretamente?

Pelo Hobsbawm a gente vê o século XX como período das catástrofes, como o século do debate do final da racionalidade, da ideia de que seria possível se alcançar um mundo mais justo, e a percepção de que a gente estaria longe disso e, portanto, há uma imersão em um "sem sentido" da existência, do pensamento e do próprio ato de pensar. Nisso vem uma desconfiança das grandes teorias, das grandes hipóteses históricas e claramente isso marca a literatura. Passa-se a fazer uma literatura de desconfiança em relação à emancipação humana e ao entendimento, e a forma da narrativa consegue expressar isso de maneira muito contundente, porque você tem a linguagem do romance se tornando mais e mais autodestrutiva, mais autocrítica, e daí você observa esse caos do mundo refletido diretamente nas formas dos romances e o romance se faz então tanto expressão quanto parte desse caos. 


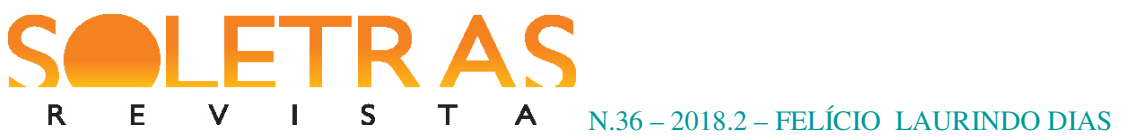

Soletras: No tocante aos autores que vêm produzindo literatura hoje, mais especificamente, narrativas que entrecruzam o discurso literário e as convulsões da história, desestabilizando possíveis fronteiras que ainda persistem entre os pares histórico e literário, penso numa determinada comunidade de escritores que estão se dedicando incessantemente a esse problema. Cito Michel Laub, Bernardo Kucinski, Milton Hatoum, Bernardo Carvalho, dentre outros. Muitos desses escritores dissimulam ou mesmo desestabilizam os limites entre ficção e autobiografia, até mesmo trazendo à tona termos como autoficção e escritas de si. Cito a entrevista ao Jornal O Globo (2013), em que Laub nos deixa algumas considerações sobre Diário da queda não ser uma ficção autobiográfica sobre a tragédia de Auschwitz, mas sim de personagens e tramas que vivem às sombras do que foi Auschwitz e como essa dívida histórica ecoa em três diferentes gerações. Laub diz que há muito dele ali, alguns dados biográficos, mas que claramente passam por certo filtro ficcional, justamente nesse jogo entre memória e ficção, incidindo sobre o que eu ouso chamar de uma ficção às sombras da catástrofe. Em outros termos, é algo em que você até toca, no seu artigo para o livro Ética e pós-verdade, ao colocar que o que está em jogo em certas construções ficcionais é menos o acontecimento da tragédia, mas muito mais o que o antecede. Nisso, pensando nesse passado que antecede a tragédia pessoal, política e histórica, você enxerga a sua escrita, ou mesmo a de outro escritor hoje, dentro dessa literatura às sombras da catástrofe ou para você esses limites nunca foram uma questão?

A gente olha com alguma distância para um século, talvez de maneira uniforme demais, mas há também uma questão geracional na forma de lidar com essa sequência de catástrofes. Há ali no início do século XX uma maneira muito direta de lidar com o desastre na literatura, como uma trilogia pós-guerra do Samuel Beckett, entre 45 e 50, que é uma autoimplosão da forma do romance pra dar conta da autoimplosão do continente europeu, assim como também é um modo muito direto de lidar com o trauma histórico. É, nesse caso, um jeito de tentar com que a narrativa reflita muito diretamente ao que é externo a ela. Ao longo do tempo, me parece que a forma de se referir a esses acontecimentos vai se tornando mais sutil e alusiva, e você tem narrativas que só tangenciam os acontecimentos históricos e não narrativas que de fato querem ser o retrato cru desses acontecimentos. Sinto que é fruto também da desconfiança do pensamento teórico, sendo uma crise do narrar e do romance, mas também é crise da historiografia, uma crise da biografia, do pensamento e das ideias, e você tem aí então outra possibilidade.

Soletras: Tratando especificamente da sua obra A resistência (2015), romance cujo eixo central também se fixa em torno de outro evento catastrófico e traumático para a história, os regimes ditatoriais no Brasil e Argentina. A resistência ressignifica esse evento traumático a partir de uma visão minuciosa e minimalista que evoca os pequenos atos por onde o trágico emerge, mascarado pela banalidade do cotidiano. As diásporas, as migrações, as guerras e a 


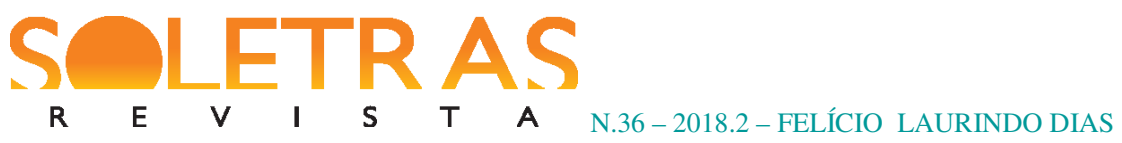

ditadura denotam a presença de um fantasma que ronda o presente. Tudo isso é transmitido ao leitor por meio de pequenas tramas, recordações precárias que atravessam fotos, objetos e relações afetivas. Gostaria que você comentasse um pouco essas questões da ditadura na sua escrita e se você acredita que seu texto se insere nessa forma de escrita, uma estética que se constrói a partir dos objetos e espaços na ficção para lidar com esse débito com o passado traumático.

Depois da publicação de A resistência, que é uma busca identitária, ou uma busca lateral por uma identidade perdida, e marcas do passado que habitariam na minha existência e na dos meus familiares, meu pai veio conversar comigo, assim como a gente já vinha conversando ao longo de toda a escrita do meu romance. Mas dessa vez ele veio me contar que ele tinha ido atrás de informações sobre seus pais e seus avós, e havia descoberto, enfim, que meus bisavós morreram em Auschwitz. A gente só tinha uma informação vaga, algo como "foram deportados aos campos e não se sabe o que aconteceu". Não havia qualquer investigação mais precisa, e agora como essas informações são muito mais acessíveis, ele conseguiu pelos nomes e documentos chegar a essa informação mais apurada. Mas o que me chamou a atenção nessa história não foi o fato de eles terem morrido em Auschwitz, porque algo como ser deportado para os campos já significava isso. Entretanto, o que me tocava era o fato de que não se falava na família dentro da casa dele, bem como não se discutia esse trauma e o envio da família aos campos. A resposta de meu pai foi muito significativa, muito representativa desse referencial geracional: não se pensa as questões históricas em função das trajetórias pessoais; ele [meu pai] se interessava muito pela questão do Holocausto, pela migração, pelo trauma histórico, mas ele pensava isso à luz de outros fenômenos muito mais amplos, talvez sociais e políticos, por exemplo, ligados ao marxismo. Então, era uma coisa que para mim demonstrou muito claramente um corte geracional. Agora, ele próprio, incentivado pelo meu texto e tantos outros relatos e ficções que fazem uma apreciação mais subjetiva dessa questão, subjetivou o seu passado, foi atrás dessa trajetória pessoal que ilustra e representa uma coisa mais ampla, mais social, mais histórica e mais política. Para mim foi uma marca. Nesse caso, acho que a literatura que se fazia décadas atrás sobre o trauma histórico era uma literatura que estava mais preocupada com os fenômenos gerais do que com a particularidade da existência. Aliás, hoje, parece ter uma tendência vasta geral de recuperação das próprias raízes, da procura desses fantasmas que você menciona, a procura desses traumas que ficaram, em alguma medida, relegados ao passado, mas que reverberam constantemente na nossa existência. Quando a narrativa do passado se subjetiva, você passa a 


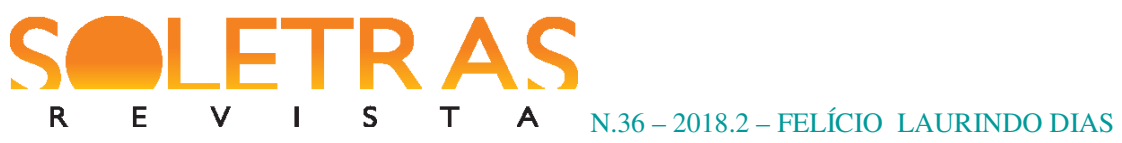

procurar os vestígios da existência passada nos elementos mais acessíveis do presente. Ao mesmo tempo, se cria um panteão de recursos possíveis. É possível observar isso se repetindo em diversas narrativas, como, por exemplo, textos escritos no passado, arquivos familiares em vídeos, fotos, criando certa ideia de que, quem tiver mais elementos tem mais para produzir e escrever sobre o passado. No entanto, os livros mais consistentes e potentes, em minha opinião, oferecem uma desconfiança em relação ao que o material proporciona. Você já não pode confiar na veracidade da fotografia, pois a fotografia é um discurso sobre o passado, e não um testamento do passado. Mesmo a presença das coisas, como estar na casa onde aconteceu um evento ou desapareceu alguém, não é estar diante do fato, você está diante de certa materialidade que evoca com distancia esse passado. Mesmo pessoalizando a questão você não consegue de fato acessar nenhum tipo de verdade, que é outra marca dessa leitura feita hoje. Não se quer dar conta da catástrofe ou do trauma, esse tipo de valorização perde sentido, porque as reverberações dos fatos são múltiplas e têm características mais variadas. Por isso, o tipo de literatura ou autoficção que mais me interessa hoje é a que desconfia de si mesma e desconfia da própria capacidade de reconstruir o passado.

Soletras: A literatura, em algum sentido, pode reforçar ou afirmar pressupostos sociais, históricos e culturais, mas principalmente políticos. Vemos hoje filmes, noticiários e séries de $T V$ confundindo as relações entre as (im)possibilidades de se representar um sentido de realidade mínima e o total descompromisso ético com a ficção a partir da distorção da realidade. Como é a consciência do discurso político na sua literatura em relação a uma ética da ficção, desde as temáticas colocadas até as construções de personagens? Ou melhor, o que seria uma ética da ficção pra você hoje?

O romance vive um momento tenso e de difícil resolução quanto a essa questão, tanto quando se está próximo de uma narrativa subjetiva, pessoal e íntima, quanto se está distante do outro, inventando e fabulando tramas distantes de uma existência própria. Sendo assim, em ambos os casos a questão ética se faz presente. No primeiro caso, lidar com essa matéria histórica envolve muitas responsabilidades, pois você está colocando pessoas em jogo, de modo que há a criação de personagens baseados em pessoas cuja existência está firmada no presente e passado, e por isso há uma responsabilidade ou compromisso com essa matéria. No meu caso, se converteu num compromisso com a sinceridade, porque eu sentia que pra falar eticamente sobre esse passado, sobre os meus pais e meu irmão, eu deveria buscar o discurso mais sincero possível, o que não significa abdicar de recursos da ficção, mas sim uma tentativa de dar conta de certa realidade e mesmo consciente dessa impossibilidade. Mas é uma tentativa 


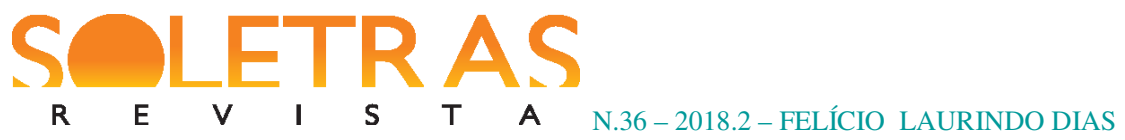

de debater questões que se colocam efetivamente em nossas vidas, de debater a partir de uma multiplicidade de vozes, sendo que outro compromisso era que não prevalecesse somente a minha visão dos fatos. Então, foi preciso internalizar no romance outros discursos, como as palavras dos meus pais e dos meus irmãos, o que resulta num romance mais multivocal e múltiplo. Contudo, no presente há, em qualquer instância que se ficcionalize, certa responsabilidade junto à liberdade que se tem para narrar. Vejamos o seguinte caso. Pensemos num romance que ficcionalize a figura de um torturador. Nesse caso, embora você tenha a liberdade de fazer isso, eventualmente você pode estar fazendo algo antiético. Se o efeito disso é de fato a exaltação da tortura, eu vou ser um leitor tentado a recusar essa narrativa, por mais virtuosa que ela seja. Se o efeito for a imagem do torturador que acarrete um debate mais complexo, assim como as implicações éticas para que ela indique o contrário da exaltação, é uma outra coisa. Mas aí há também uma ética do próprio autor. Os efeitos de uma obra literária são muito impalpáveis pra você determinar, e nesse caso entra a função da crítica. Explico-me. As obras não são inocentes de partida, é preciso de uma crítica, tendo em vista que as obras participam do mundo, são discursos sobre o mundo e elas podem contribuir para a nossa emancipação ou agravar a situação de repressão. Olhemos o caso de Lolita, de Nabokov. Vamos continuar lidando com um texto que naturaliza em grande medida a pedofilia, com alguma tranquilidade acrítica ou vamos aceitar essa obra importante, mas tratando criticamente da complexidade que o caso traz? Eu sou um defensor da liberdade autoral artística, mas essa liberdade convoca uma discussão ética sobre esses atos narrativos. Toda obra tem pertinência, mas é a crítica literária que vai discutir se aquela obra tem um caráter em algum caráter libertário ou reacionário. A ética não só se apresenta na figura do autor, no instante de criação dessa obra, mas é algo que vai permear todo o mercado e o sistema literário.

Soletras: A partir de algumas leituras de suas obras, tanto em A procura do romance quanto em A resistência, é possível perceber possibilidades bastante interessantes de diálogos com muitas correntes da teoria da literatura, diria que quase uma provocação teórica muito bem colocada. Nisso, ainda levo em conta parte da sua biografia e sua relação com o meio acadêmico dos estudos literários, claro, sem pretensão de usar isso como chave-leitora para resolver qualquer questão em sua obra. Então, sem querer retomar questões cansadas como as da intencionalidade do autor, há algumas referências propositais, mais teóricas, na composição das suas obras e que digam respeito à sua formação intelectual? 


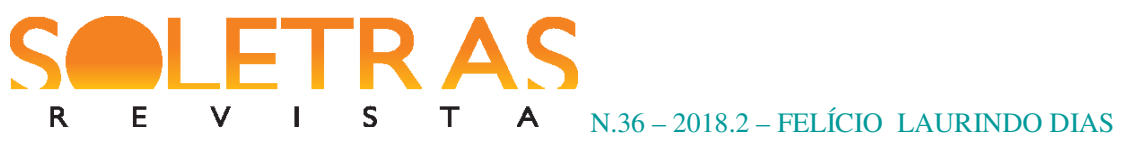

Para mim, são questões que desde o início estão interligadas. O meu primeiro livro, Literatura e cegueira, que foi um pouco mais cuidadoso em sua composição, já era meu trabalho de conclusão de curso de Jornalismo, na ECA (Escola de Comunicação e Artes da Universidade de São Paulo). A procura do romance é uma reposta às questões que eu vinha estudando no meu mestrado, sobre a impossibilidade de narrar e as questões do romance. Havia ali uma questão teórica em alguma medida, que era a dissertação, e paralelamente eu escrevia um romance que queria internalizar esse paradoxo. Um romance em uma época em que se denuncia a morte do romance e amplamente se difunde a impossibilidade de narrar. Depois, no doutorado, já no departamento de Teoria Literária da USP, começo a me relacionar com esses hibridismos contemporâneos, com essas narrativas visitadas por outros discursos. Nesse ponto, talvez a relação tenha se invertido, porque antes comecei a escrever A resistência e daí preocupações pessoais, de outras razões, e não teóricas, surgem. Me vi teorizando a respeito de outros autores que se debruçavam sobre esse fenômeno, sobre esse mesmo método, e por isso acabei teorizando quase como fruto de processo de se estar escrevendo autoficção, e isso implica a ideia da impossibilidade contemporânea da ficção.

Soletras: Há um conjunto de escritores que construiu uma poética muito firme e consistente a partir desse trânsito entre literatura, teoria e gêneros híbridos, como Vila-Matas, Ricardo Piglia, Julio Cortázar e J. M. Coetzee. Aliás, essa divisão era até algo impensável para sujeitos como Jacques Derrida, que sempre esteve nesse não-lugar muito frutífero entre literatura e filosofia. Você acha que esses limites inaparentes entre escritor e teórico se fundem na sua obra e trazem algum impacto criativo que só essa formação poderia proporcionar?

A obra fica muito marcada por isso. São autores que se preocupam com o passado da própria literatura e da forma da literatura, e eu gosto de me vincular a essa tradição. Eles não pensam o romance sem pensar a história do romance ao longo dos séculos, sendo a literatura hoje resultado de algo que se processou num pensamento criado por muitos escritores. Há autores fazendo literatura, muito interessante inclusive, sem uma preocupação com o passado. Mas para mim, pessoalmente, os que mais me atraem são os que estão mais refletindo constantemente a pertinência dos seus romances na relação com os romances do passado, aquilo que se cristalizou e se consolidou no tempo. São autores que pensam o romance como mais uma forma de representação da história, e assim o romance não estaria isolado das ideias do mundo. $\mathrm{Na}$ verdade, o romance e as ideias estão em constante interação, porque você acaba produzindo um romance que reflete certo pensamento sobre o mundo, assim como uma 


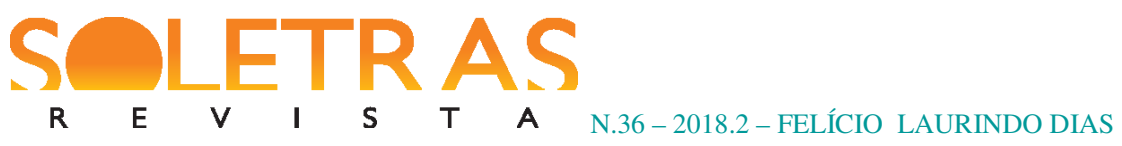

concepção histórica, e a forma do romance vai espelhar algo dessas preocupações. Para mim, é uma percepção clara que o romancista não é um sujeito que vive isolado, comprometido só coma própria arte, mas que, sim participa de um debate maior, político, e é mais um com uma voz numa participação no debate social. Cada forma e cada linguagem te propõem abordagens e ideias muitos diferentes. Por isso, eu não abdico da teorização por ser escritor deuma obra ficcional. Pelo contrário, certas ideias me convidam à construção de outros discursos. Eu fiz uma tese convencional e deixei intacta a linguagem acadêmica. A linguagem acadêmica também se problematiza e se aproxima do ensaio e esses hibridismos vão transformando todas as linguagens, resultando num movimento dialógico.

Soletras: Qual o lugar da universidade hoje no debate literário?

Eu tenho uma perspectiva muito positiva. Parece que ali se aprofundam muitos debates. Os debates mais rigorosos sobre literatura que eu tive foram naqueles espaços. Mesmo uma defesa de tese ou uma qualificação são momentos de aprofundamentos de ideias. Ali se cria, com muita profundidade e rigor, um debate que o mercado editorial tende a recusar. Não interessa tanto um evento literário que aprofunde demais o discurso e que faça uma exposição rigorosa de certos conceitos e noções. O evento literário tem que ter uma leveza a que a academia não se propõe e que ela não exige. Ao mesmo tempo, às obras literárias, no atual contexto do mercado literário brasileiro, exige-se certa leveza e brevidade que a academia não pede. A academia ainda é um lugar de debate complexo e profundo. Há o rigor, é claro, que é importante, mas também é um risco. Risco, digo, no momento em que se torna dogmático. Há momentos na academia de exigência de linguagem e exigência de um rigor que talvez não contribua ao pensamento e ao debate das ideias. A universidade ainda está muito fechada, por exemplo, ao hibridismo e a uma literatura feita naquele contexto.

Soletras: Permita-me uma colocação mais longa, mas também necessária para contextualizar a minha pergunta. Jaime Ginzburg, professor da USP, em sua tese de livredocência, intitulada Crítica em tempos de violência, destaca que há autores fundamentais da literatura brasileira moderna que elaboram suas narrativas em torno da condição humana e seu caráter agônico, de acordo com o contexto histórico brasileiro. Há, nesses escritores, certa resistência a um positivismo histórico ou mesmo, àquilo que Walter Benjamin chama de história dos vencedores ou narrativas burguesas. Ainda, o que se chama de era das catástrofes, lá em Hobsbawm, por exemplo, foi também um período do século XX em que se desperta um interesse pela memória em oposição ao modelo historicista burguês. Essa configuração, hoje, parece ainda estar muito presente nas construções das narrativas no 


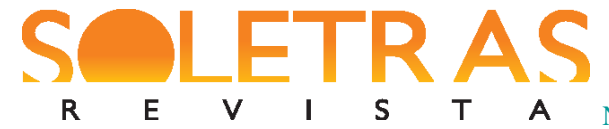

N.36 - 2018.2 - FELÍCIO LAURINDO DIAS

cenário brasileiro, principalmente no tocante a um contexto sombrio em certo cenário de golpe de estado muito conivente com uma política de esquecimento ou amnésia histórica. No entanto, lembro-me de Jean Norton Cru, importantíssimo historiador francês que muito refletiu sobre o testemunho em War Books: a study in historical criticism e que, apesar de muito positivista na sua apreensão historicista, ainda sim é exímio e belíssimo texto, considerado fundador do gênero, pois tratava do choque na volta de soldados da guerra, e nisso findava a ideia de testemunho autêntico que, diferentemente de Benjamin, acreditava que esses soldados teriam muito a dizer. Nisso, Cru estabelecia uma espécie de hierarquia dos gêneros, em que o romance ocuparia o último lugar e seria quase um inimigo do testemunho. Há, claramente, uma valorização do documental, ainda muito creditado às grandes narrativas. Por vezes, em seu texto de A resistência há passagens como "Não, não há ficção". Nisso, pergunto: Você vê a literatura como uma forma de enfrentamento a essas instituições do poder que contribuem, a todo o momento, para um esquecimento do passado?

Um debate que tem me interessado bastante é a questão da pós-memória, que em alguma medida se relaciona com isso que você traz e tem sido rico porque não é unânime o conceito de memória coletiva e pós-memória. Ainda é memória, mas se subjetivou de tal maneira que dá mais conta de algo individual do que social. Acho interessante, pois se torna importante não pela certeza, mas pela controvérsia. A sua questão me parece fundamental para tratar de um presente no Brasil. Você nota como no Brasil, em diversas manifestações, a memória está em jogo e que é fruto de uma controvérsia: uma distinta visão de pais que se assentou agora e nos deixa duas visões históricas, sendo que uma delas quer silenciar o passado. Nesse sentido, há um passado relativizado sob uma concepção de que a gravidade está suspensa, como no caso da ditadura, construindo uma narrativa em torno da ideia de que não há gravidade na ditadura militar. O nosso atual presidente, eleito de forma não democrática, Michel Temer, nesta semana afirmou que o golpe militar de 1964 foi uma vontade popular. Nisso, constantemente estão se relativizando crimes na ditadura militar e a gente não conseguiu de fato chegar a uma visão histórica mais consistente e mais difundida desse passado. Esse discurso ainda ganhou mais projeção sob a ideia de que a ditadura tinha as suas qualidades e que foi o melhor momento da história. Isso se manifesta em vários pedidos de intervenção militar que, por sinal, já vêm acontecendo em mais sentidos e contextos brasileiros. Nesse cenário, quando vem à tona e ganha força um discurso retrógrado de valorização da ditadura, a literatura que se propõe a encarar criticamente esse período vai ser rejeitada com quem compactua com esse projeto de retrocesso. Por isso há uma crítica a tudo o que se faça de memória relacionada a esse passado, como o caso da Comissão da Verdade. Então, para certa parcela da população, esse discurso é indesejado. Falo desse discurso mais progressista, que retoma criticamente o passado e revê a ditadura e suas forças de retrocesso, tal como ela foi. 


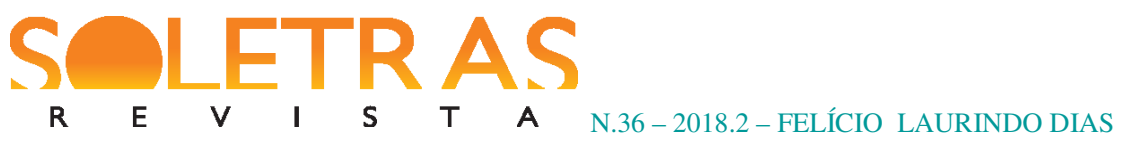

Para outra parcela do país, não me parece nem um pouco esse caso, pelo contrário: há uma necessidade de ouvir de novo o que foi a ditadura. Há alguns fatores que não foram contemplados e compreendidos, quer dizer, a gente ainda continua lidando com uma ditadura brasileira em que há mais de 400 desaparecidos, assim como desconsideramos as vítimas camponesas e indígenas na nossa história, ou seja, há muito a ser compreendido. Dizer isso em uma obra literária é ser repetitivo, mas há também essa necessidade de ouvir o que isso representou. A recepção do meu livro foi um pouco isso, houve uma vontade de ouvir mais uma vez o que foi essa opressão, mas acriticamente. De fato, não há tanto uma reflexão dos fenômenos da ditadura militar que ainda se mantém, digo isso porque há ainda preservados os alicerces da opressão, como uma polícia que mais mata no mundo, o genocídio da juventude negra e um anseio por censura e tortura. É só analisar obras do cinema, como Tropa de elite, em que você tem um torturador aceitável, que provoca até risos da plateia. Tendo isso em vista, tortura, censura e desaparecimentos fazem parte de um tripé da ditadura que permanece muito ativo, e sobre isso se fala muito menos do que sobre os crimes da ditadura em si.

Soletras: Raduan Nassar se pronunciou sobre o Prêmio Camões e provocou um efervescente debate do lugar do escritor hoje que, não somente anterior e posterior à sua obra, parece também ocupar lugar muito estratégico nas discussões políticas. Em alguns momentos, é muito difícil não atrelar vida e obra. Lembro-me, também, do caso do Luiz Ruffato, na feira de Berlim, cujo discurso, politicamente contundente, foi muito utilizado em teses e artigos no meio acadêmico, quando se queria discutir a narrativa de hoje. Essa performance do escritor, à primeira vista, parece trazer novamente ao debate, as calorosas discussões em torno não mais da morte do autor à la Barthes, mas do retorno do autor como sujeito muito mais ativo e político. Você acha que essa performance pode se somar à leitura das obras ou pode ser um empecilho na compreensão de sua produção? Ou ainda, você acha que a obra por si só já é um ato político e não deve ser atrelada às performances e opiniões do autor?

Em vários fenômenos contemporâneos o hibridismo se constrói com essa relação do fora do texto. Você percebe que a relação biográfica do autor tem importância na concepção e compreensão da própria obra. De fato, a participação pública do autor ganha outra natureza e relevância; a obra nesse momento já rompeu com a noção de primado do objeto e de que só interessa o que a obra diz de si mesma. Muitas produções literárias estão propondo uma relação franca e direta com o extraliterário. Para além disso, num contexto atual, os escritores estão sendo muito convocados a aparecem publicamente, não são mais essas figuras fechadas em suas casas, escrevendo na solidão romântica da imagem de escritor solitário. Agora eles estão sendo convidados a se expor mais. Á princípio, isso se dava só por uma aproximação de 


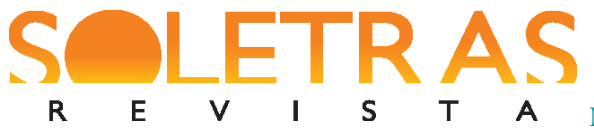

N.36 - 2018.2 - FELÍCIO LAURINDO DIAS

curiosidade em relação à figura do autor. Explico. Os agentes literários de um modo geral não propõem que o autor se coloque, se posicione ou tome partido, mas que se apresente e que o público conheça essas figuras por detrás das obras em si. Havia um momento em que parecia que o narcisismo de certas obras contemporâneas se refletia nessas aparições públicas em que o escritor era um sujeito bem sucedido, o self-made man que estava ali defendendo seu caso de sucesso e de como ele se tornou um palestrante, não muito diferente do que acontece no meio empresarial nesse tipo de circunstância. No entanto, escritores críticos e atuantes no meio literário romperam com esse enquadramento, não aceitando aparecer publicamente para falar unicamente sobre os processos criativos ou caso de sucesso, mas querem, agora, se posicionar e travar um debate/embate público. Retomam, assim, uma tradição que já estava ali, por exemplo, no boom latino americano, em que havia escritores muito bem posicionados, debatendo o engajamento do escritor, o que é muito diferente do engajamento da obra em si. Então, você vê um engajamento mais forte, até porque no meio literário há uma reação da grande maioria ao que está acontecendo no Brasil hoje, como o retrocesso do golpe, e aí a literatura aparece como esse lugar de resistência.

Soletras: "Estamos sempre indo pra casa", frase construída por Raduan Nassar e verbalizada por seu personagem André, em Lavoura arcaica, parece expressar uma das situações limites do ciclo que se repete no romance, mas principalmente de uma narrativa de retorno, como no excerto de A resistência:"(...) queria falar do meu irmão, do irmão que emergisse das palavras mesmo que não fosse o irmão real e, no entanto, resisto a essa proposta a cada página, fujo enquanto posso para a história dos meus pais”. Pensando nesses limites intertextuais, em momentos distintos da nossa literatura, sua obra parece também ser permeada por essa sensação de estar sempre retornando. Nesse caso, como se dá a questão do retorno na sua escrita? Como é a sua relação com a literatura e com o ato de retornar à família?

Para mim, quando passei a escrever a partir desse ponto mais biográfico, ficou evidente que a escrita seria esse processo de retorno, uma visita ao passado e, consequentemente, à memória. Inclusive, há retornos físicos, como o espaço da casa em Buenos Aires, aos registros históricos, às fotografias, às anotações, aos documentos. Tudo isso é revisitar, algo que no seu momento eu não conhecia. Talvez o que esteja na base disso é a percepção de uma precariedade da própria existência cotidiana, ou seja, você não consegue compreender de fato o que está vivendo, você não consegue assimilar os sentidos de tudo que se passa e a literatura funciona justamente como esse mediador, de maneira que se converte nessa busca, nessa revisão dos sentidos do passado e das relações. Já disse uma vez: "escrevo porque não 


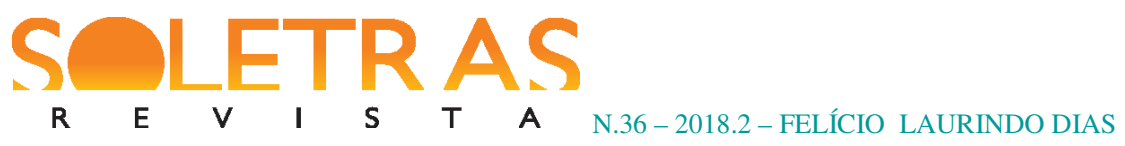

consigo no momento exato, espontaneamente, responder às circunstâncias, me colocar e atuar como eu esperaria de mim mesmo". Por isso, para mim, escrever é me reposicionar, é reelaborar e me redimir. Eu fui percebendo aos poucos como a ideia de redenção aparece várias vezes na minha escrita, como se houvesse algo da existência real, cotidiana e familiar e de que fosse preciso me redimir. A literatura se faz nessa busca. Há em certa medida uma dívida com o passado que a literatura não vai saldar, mas ela possibilita a compreensão desse passado, você revista os sentidos e, como na psicanálise, encontrar as palavras para dizer o que se passou e, até de forma misteriosa, a literatura também transforma o que se passou simplesmente ao encontrar palavras. Não é preciso que ela incida sob a realidade e modifiquea, mas encontrar palavras e encontrar sentidos para isso, já é transformar.

Soletras: Tenho me debruçado bastante sobre temas históricos que reverberam ainda hoje de forma espectral na literatura, sendo essa a temática da minha tese de doutorado em literatura brasileira. Seguindo esse pensamento, em Espectros de Marx (1994), Jacques Derrida aponta uma multiplicidade de espectros e imagens fantasmagóricas que nos frequentam ou que historicamente nos frequentaram, tais como o espectro do comunismo e do marxismo; o espectro neoliberal e a produção de fantasmas em nível econômico, político, social e midiático mundial. Em consonância, no livro Mutações da literatura no século XXI, no capítulo "Espectros da modernidade literária", a professora Leyla Perrone-Moisés me adianta parte de minha tese de doutorado acerca da ficção hoje, ao afirmar que na literatura, principalmente na contemporaneidade, o espaço-tempo é propício para os espectros, uma vez que jornais, noticiários de TV, redes sociais, cinema e outros meios de produção audiovisual “(...) nos cercam de imagens imateriais, espectrais” (PERRONE-MOISÉS 2015, p. 151). Nesse caso, observando uma específica passagem de A resistência (2015, p. 35), a saber: "são seres históricos esses que eu vejo. Sua aparição pontual na fotografia é uma culminação de caminhos pretéritos, uma entre muitas culminações dessas vidas complexas que se entrelaçam e se permeiam com um passado coletivo". Você consegue identificar esse teor espectral na sua literatura? Principalmente por se tratar de um livro às sombras da ditadura militar. Gostaria que você comentasse um pouco a respeito.

Sim. Eu tento capturar da maneira mais cuidadosa possível o passado e essas figuras do passado, como a existência de um irmão, do pai etc. Eu busco capturar figuras que não estão lá, e existem de outra maneira no presente. Então, é buscar aquilo que se manifestou e se dissipou, se esvaiu, e já não está mais acessível, e haveria aí algo de espectral. Eu acho interessante a sua leitura, mas não sei se em algum momento eu cheguei a pensar nesse caráter fantasmático da sua leitura, que é muito interessante. $\mathrm{O}$ que eu sei é que há o caráter impalpável dessas existências, tudo o que essas pessoas foram já não é mais acessível e assimilável. Então, toda tentativa de contemplá-las vai ser uma construção de simulacro. 


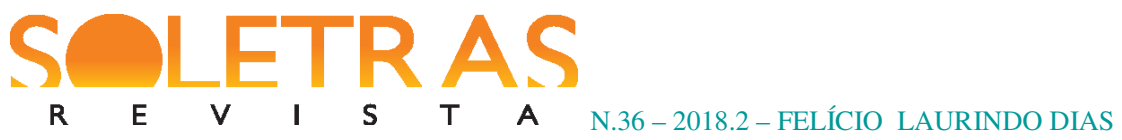

Quando você fala de fantasma, eu penso em Marta Brea, que no meu livro é a figura do desaparecido tal como se manifestava dentro de casa. Ela nunca deixa de estar presente, sendo uma figura que representa algo, e há essa associação de um Holocausto interno, um Holocausto que se dá na esfera particular e que, naquele contexto, tem o nome de Marta Brea, essa desaparecida. São formas em que esses fenômenos mais amplos se singularizam na existência e na obra literária também. Acho muito interessante essa leitura que você está fazendo, a existência de fantasmas muito mais vastos e amplos do que as figuras específicas que desapareceram ou a figura específica que sofreu ou trauma ou os meus bisavós que morreram em Auschwitz. Mas mais importante do que isso são essas muitas maneiras como os traumas históricos se singularizam nas relações individuais e vão ganhando outros nomes e outras acepções. Ao mesmo tempo, não tinha me ocorrido, a noção de um espectro ainda maior seriam as utopias e a possibilidade de uma militância hoje, algo que está constante na voz do meu narrador ao longo do livro. Os pais foram militantes e se envolveram, mas o narrador se pergunta, hoje, como ser militante e engajado politicamente, num momento em que certas utopias se converteram em espectros.

Entrevista concedida em 29 de março de 2018. 